\title{
The Key Factors Affecting Internal Quality Education Services in Secondary Vocational Schools
}

\author{
Bambang Trisno $^{\mathrm{a}}$, Daniar Nurdianto ${ }^{\mathrm{a}}$ \\ ${ }^{a}$ Electrical Engineering Education Department, Indonesia University of Education, \\ J1. Dr. Setiabudhi 227, Bandung 40154, West Java, Indonesia \\ ${ }^{1}$ bangino2012@gmail.com
}

\begin{abstract}
The objective of this research is to construct a model of the internal factors which will influence the level of quality services in the organization of vocational school. This research empirically explore the correlation between the internal quality service and the school change factors. With analysed the capacity of school infrastructures, the world business and industry, school climate and leadership based on the perspective of principals and teachers from 30 vocational secondary public and private schools in Bandung, West Java. The analysis using quantitative methods with path analysis (used SPSS 2.0) to determine the amount of factors which the most dominant and influential to internal quality service. The results showed that the leadership and school climate has a dominant impact than the other factors and give a significant influence to the pattern of internal quality services in vocational secondary school.
\end{abstract}

Index Terms: internal quality services, ability to manage internal factors

\section{Introduction}

As a sub-system in Indonesia's national education system, technical and vocational education has always played a crucial role in creating skilled human resources. At the secondary school level, on average between one-fifth and one-quarter of enrolled students are study at secondary vocational schools (vocational school,), while the remainder study at general academic schools (High school). In recent years, the Ministry of National Education has committed itself to the expressly stated goal of increasing the proportion of vocational school students to " $70 \%$ vocational school students and $30 \%$ the senior high school students" at senior secondary level. In the theory of vocational education, education leads to fit individuals with the required work. To fit education and vocational training with the kinds of jobs needed by society, it is very difficult due to needs of the job changing rapidly and not easy to predict. To adapt to the various internal and external factors (environment), it certainly needed a school leader who is able to determine the characteristic scale of priorities in developing leadership and school climate models are built. From decentralization policy of education, government has given duties, functions, authority and greater responsibility in providing education to local school. Decentralization of education aims to improve service quality and performance of vocational education for equity, quality, relevance, and efficiency of vocational education. School should create effective internal customer focus service system. However, due the implementation facing many problems caused by the growth number of customers and the complicated demands. The negative access school internal services have occurs such (1) services have long procedure and wasting time; (2) unqualified (input-process-output) (3) service pattern become rigid, inefficient and tend to disadvantage customer [1]. Following this approach, teachers as internal customer requiring service quality is understood as an internal customer of school management who supplies the internal service. So the principal as the agents of change must be able to manage change - a change in the organization into a competitive advantage [2] and creates an internal culture that serves as a foundation for total quality management.

\section{Internal Service Quality in Vocational Secondary School}

Internal service quality is the prerequisite for overall company performance [3]. [4] Every employee and unit, both a service provider and utilizer and that internal service quality greatly impacts the service quality to external customers.

They designed INTSERVQUAL an internal service quality measurement scale based on the "gap model" to successfully measure the difference between internal customer's understanding and expectation from frontline service staff to support service and consequently, to recognize key factors influencing internal service quality among employees. Internal service quality includes tangibles, reliability, assurance, responsiveness and empathy. Tangibles refer to service tools, for example, facilities. Reliability is the ability to carry out the promised service reliably and correctly. Assurance refers to the fact that the provided service makes colleagues feel confident in being equipped with the required knowledge and courtesy. Responsiveness refers to an employee reacting swiftly to colleagues' demands and providing sincere and timely service. Empathy refers to understanding demand and providing convenient service to colleagues with communications catered to their needs. This research explores the impact of school input on change management process and the internal service quality of Vocational Secondary Schools.

Environmental quality of education is divided into two parts, namely the quality of academic services and the quality of learning, which is defined [5] as follows. The quality of academic service is composed of selected tangible items in the student environment and non-tangible relationships between instructor and student, while instructional quality describes the interaction between faculty and students, primarily taking place in a traditional classroom. In this situation requires a leader based on the principal's role and who responsible in quality that obliged to direct, develop, and guide school personnel in order to carry out their duties effectively and efficiently. To that end, the implementation of principal leadership contributed greatly in achieving the goals of the school. Leadership at the school 
will be strongly influenced by the context of education as part of school organizational characteristics. Leadership is a high priority issue for many people concerned with education these days. Reformers depend on it. The public believes that it is what schools need more of. It is not surprising, then, that so many people are trying to make a living peddling their latest insights about effective educational leadership. Indeed leadership by adjective is a growth industry. We have instructional leadership, transformational leadership, moral leadership, constructivist leadership, servant leadership, cultural leadership, and primal leadership [6]. A few of these qualify as leadership theories and several are actually tested leadership theories. But most are actually just slogans. Consider, for example, the terms, especially popular in North America, "instructional leadership" and, in England, "learningcentered leadership": they typically serves as synonyms for whatever the speaker means by "good" leadership - with almost no reference to models of instructional or learningcentered leadership that have some conceptual coherence and a body of evidence testing their effects on organizations and pupils. Educational infrastructure is an educational input factors which are very influential in the ministry of education, research [7] mentions in particular the influence of the size of the school means to the achievement of students and the learning process.

School infrastructure i.e easily influenced by changing technology, especially for vocational school graduates who are skilled in creating. Dimensions infrastructure including class size, quality of construction, practice space, laboratories, and ICT facilities. The linkage between employers and industry development, in vocational education providers today are obligatory. The Role of Business and Industry is a great start of competency standards define, formulate the curriculum together, engaged in the learning process and provide certification of the competency test, so that vocational education graduates are ready to use force in the world of Business and Industry. Dimensions participation in this study are, the school program improvement (dual system education program), advisor of school problem and school technology development.

\section{The linkage between school and community (employers and industry) and change management}

School efforts to involve families and the community (DUDI) learning is an excellent approach to creating student achievement. According [8] program participation can be managed by the school has four components as follows: (1) the participation of the group; (2) four types of participation (parent participation, communication, volunteering, learning at home, decision-making and collaboration with community) ; (3) The work plan aimed at student achievement; (4) Evaluation and continuous improvement. DUDI participation has a positive impact on student attendance, increase in grade, graduation rates, the impact on the labor market.

\section{School Climate}

Current climate is often identified as a component of a social system and a situation that is associated with thoughts, feelings, and behavior of its members that are temporal and subjective. School climate [9] is the quality of a school that creates healthy learning places; nurtures children's and parents dream and aspiration; stimulates teacher creativity and enthusiasm, and elevates all of its members. School climate describe the quality / grade school, the quality is characterized by the presence of healthy conditions for each member. The definition of a more comprehensive school climate is expressed [10] school climate is based on patterns of people's experiences of school life and reflects norms, goals, values, interpersonal relationship, teaching and practices, and organizational structures.

School climate is widely regarded, by combining the environmental aspects, aspects of student achievement, school physical and learning materials, climate may include anything from environmental aspects of the school the personalities of the students performance, level of physical activity, and the process and materials used throughout instructional procedure [9].

Reference [11] define school climate as depicted in the perception of quality teachers that can be viewed in three perspectives. Organizational climate is a relatively enduring quality of a school that is manifested in teacher's collective perception of organizational behaviour. The climate of school can be viewed from variety of vantage points; (a) the openness of behaviour, (b) the health of interpersonal relations and (c) the citizenship behaviour of teacher.

Change management framework for education especially in vocational education depend on (a) leadership; (b)milieu;(c) learning programs and (d) external context [12].

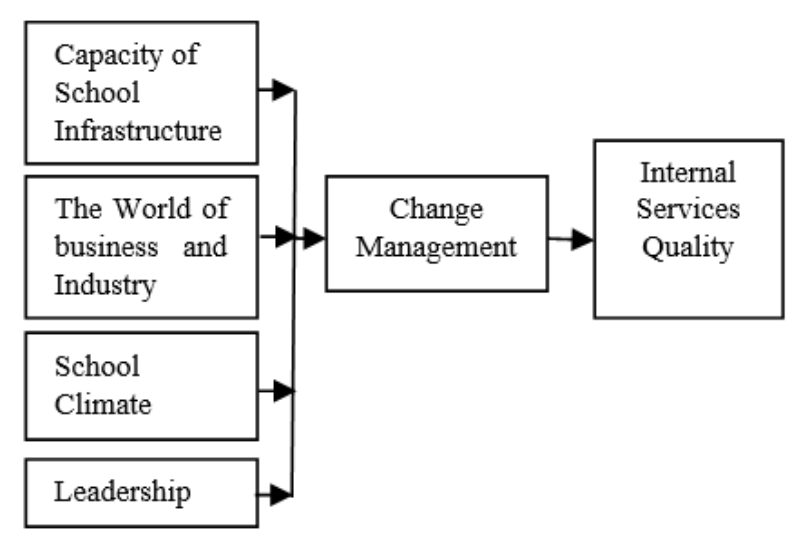

Fig. 1. Theoritical framework

\section{Method}

The aims of this study is to construct the model of internal quality services in vocational secondary school and to improve school input quality, there are capacity of school infrastructure, the world business and industry, school climate and leadership, that many researchers addressed the important influential effects of these factors on employee internal dynamics and behaviors, to discuss the influences from these two factors on the internal service quality (Z). The variables studied were the capacity of school infrastructure (X1), the world of business and industry (X2), 
school climate (X3) and leadership (X4) and change management $(\mathrm{Y})$ based on the perspective of principals and teachers from 30 secondary vocational education schools (public and private) in Bandung which consist 30 principal and 210 teachers, West Java. By using hypothesis that all independent variable will affect internal quality services in secondary school of vocational; and then using quantitative methods with apply path analysis (used SPSS 2.0) to determine the amount of variables the most dominant and influential in this study.

\section{Result and Discussion}

Based on analysis statistical data, it used X1 = Capacity of school infrastructure; $\mathrm{X} 2=$ the world of business and industry (DUDI) ; X3 = School climate ; X4 = Leadership ; $\mathrm{Y}=$ Change management and $\mathrm{Z}=$ Internal service quality.

The result of calculation and analysis for all independent variable (direct affect) $=\mathrm{X}$ to $\mathrm{Z}$ and indirect effect through $\mathrm{Y}$ represented in this table:

Table. 1. The Result calculation from statistical data for all independent variable that affects internal service quality.

\begin{tabular}{lccccc}
\hline Variable & $\begin{array}{c}\text { Correlation } \\
\text { Coefficient } \\
\text { (rY2X) }\end{array}$ & \multicolumn{2}{c}{ Path Coefficient } & \multicolumn{2}{c}{ Influence } \\
(PXY1) & (PYYY2) & Direct & Indirect \\
$(\%)$ & $(\%)$ \\
\hline $\mathrm{X}_{1} \rightarrow \mathrm{Y} \rightarrow \mathrm{Z}$ & 0,781 & 0,225 & 0,458 & 16,24 & 8,75 \\
$\mathrm{X}_{2} \rightarrow \mathrm{Y} \rightarrow \mathrm{Z}$ & 0,657 & 0,115 & 0,458 & 15,76 & 6,75 \\
$\mathrm{X}_{3} \rightarrow \mathrm{Y} \rightarrow \mathrm{Z}$ & 0,740 & 0,219 & 0,458 & 16,21 & 9,10 \\
$\mathrm{X}_{4} \rightarrow \mathrm{Y} \rightarrow \mathrm{Z}$ & 0,748 & 0,310 & 0,458 & 21,09 & 11,70 \\
\hline
\end{tabular}

Discussing the result of this research (look table.1); Development the world of business and industry (DUDI) have direct $(15,76 \%)$ and indirect $(6,75 \%)$ influences to change management, it's smaller than Capacity of school infrastructure $(16,24 \%)$ and both of variables affected to change management and internal service quality. Every secondary vocational education have a different infrastructure especially in capacity and types of modul for practices. Because everything for learning and practice depend on creativity from leadership in secondary school of education because it will influence school climate to change management process and internal service quality. Leadership in secondary vocational education is more dominant affect than the other variable, because every behaviour and traits of leadership $(21,09 \%)$ will affected climate organization of school $(16,21 \%)$ and relationship with the world business and industry to meet all of the objectives of education.

\section{Conclusions}

Leadership has a significant correlation and dominant factors among the others. Internal services quality in secondary vocational school depend on capacity and characteristic of leadership in development the organization (especially principal), in example making decision to choose of organization climate which will desire and he knows the best decision improve the facility and capacity of infrastructure which will support and affect the values every learning and practice. So every traits and behavior of leader especially the principal will affect type of climate of school will be built. In the world of business and industry, relationship with education institution is very important and become a part of partner and stakeholder which affect directly to the kind of internal quality services and type of organization climate which will be happen in the school and also influence to the life of the school organization in the future.

\section{Reference}

[1] Suryadi Ace \& Budimansyah Dasim,Paradigma Pembangunan Pendidikan Nasional, Konsep, Teori dan Aplikasi dalam Analisis Kebijakan Publik, Bandung,Widya Aksara Press, 2009

[2] Ulrich Dave \& Lake Dale, Organizational capability: Competing from the Inside Out, New York:John Wiley \& Sons, 1990

[3] Large , R.O \&.Konig, T, “A gap model of purchasing's internal service quality: Concept, case study and internal survey", Journal of Purchasing \& Supply Management 15, pp 24-32, 2009

[4] Boshoff, Christo and Gerhard, Mels,"A causal model to evaluate the relationships among supervision, role stress, organizational commitment and internal service quality,"European Journal of Marketing, Vol. 29 No. 2, 1995, pp. 23-42,1995

[5] Greiner, K., \& Westbrook, T.”Academic service quality and instructional quality", Journal of the First-year Experience and Students in Transition, 14(2). 7-30, 2002

[6] Goleman, D., Boyatzis, R., \& McKee, A. Primal leadership. Boston, MA: Harvard Business School Press. 2002

[7] Cotton,"School size, school climate, and student performance". Portland, OR: Northwest Regional Educational Laboratory,1996, $\begin{array}{llll}\text { Retrieved January } & 18, & 2006 & \text { from }\end{array}$ http://www.nwrel.org/scpd/sirs/10/c020.htm

[8] Epstein J ,"Connections count: Improving family and community involvement in secondary schools", Principal Leadership, 8(2), 16-22, 2007

[9] Freiberg, H. J. (Ed.), School climate, measuring, improving and sustaining healthy learning environments. London, England: Farmer Press, Taylor and Francis Inc.,2005

[10]Cohen, J. \& Geier, V. K, "School Climate Research" Summary:January,New York, 2010. (www.schoolclimate.org/climate/research.php).

[11]Hoy Wayne \& Miskel Cecil, Educational Administration Theory, Research and Practice, Singapore:McGraw-Hill, 2008

[12] Scott, Geoff, Change Matters :making a difference in education and training,New South Wales, Allen \& Unwin 